\title{
Media Choice Proliferation and Shifting Orientations Towards News in the United States and Norway, 1995-2012
}

\author{
Eiri Elvestad \& Lee Shaker
}

\begin{abstract}
Around the world, rapid media choice proliferation is empowering audiences and allowing individuals to more precisely tailor personal media use. From a democratic perspective, the relationship between the changing media environment and news use is of particular interest. This article presents a comparative exploration of citizens' changing orientations towards local, national and international news in two very different countries, Norway and the United States, between 1995 and 2012. Prior research suggests that more media choice correlates with a decrease in news consumption. Our analysis shows a pattern of increasing specialization in news orientation in both countries. We also find that the strongest Norwegian trend is one of specialization while the strongest trend in the United States is one of disconnection. Altogether, the results illustrate how local conditions shape the effects of global technological developments.
\end{abstract}

Keywords: media globalization, news orientation, local news, international news, news use, comparative study

\section{Introduction}

From the advent of the World Wide Web in the mid-1990s to the present, the breadth and depth of information easily available to individuals around the world with internet access exploded. The effects and implications of this proliferation of media choices are still developing and, from a democratic perspective, the plight of news in the modern media environment is of particular concern. Clearly, audience members today can tailor their media exposure to include more, less or different kinds of news. Thus far, scholars studying the relationship between the modern media environment and news audiences in Europe (Blekesaune, Elvestad, \& Aalberg 2012) and the US (Prior 2007) have primarily focused on the development of exposure to news in general or to national news. This research has shown an increase in news avoiders and a greater gap in political knowledge between news avoiders and news junkies.

News use is strongly correlated with political knowledge (Delli Carpini \& Keeter 1997), citizen engagement (Merritt \& Rosen 1995) and community attachment (Stamm 
1985 ) - but not all news is equivalent. Prior research indicates that patterns in individuals' interest in local, national and international news suggest divergent orientations to society (Elvestad 2009; Merton 1968). At a basic level, while international news consumption predicts an awareness of global politics (Curran et al. 2009), national and local news consumption predict knowledge about national and local politics, respectively (Shaker 2012). In short, different orientations towards news have implications for citizens' participation in self-governance. Consequently, it is important to study the contours of citizens' relationships with news - not just whether people are generic news consumers or not.

In this article, we examine individuals' orientations toward news at different levels (local, national, international) since the outset of the internet age to assess how the audiences for different types of news have changed as choice has increased. More specifically, we use survey data between 1995 and 2012 collected by the Pew Research Center and TNS Gallup to depict shifting patterns of news orientation in the United States and Norway. An over-time, cross-national comparative approach allows for parallel analyses in national settings that diverge in many social and political ways but share new media technology adoption timelines and usage rates.

\section{National context and news media orientation}

Following the 1993 release of Mosaic, the first fully-featured web browser, the internet became "one of the most rapidly adopted mass consumer technologies in history" (Rainie \& Wellman 2012, 61). The advent of the WWW accelerated a trend towards the expansion of media choice available to ordinary individuals around the world. What effects may flow from this increase in media choice? Will these effects be consistent across the globe? We argue that the effects of increased media choice around the world will likely differ as a result of locale-specific idiosyncrasies (Brüggemann et al. 2014; Bijker, Hughes, \& Pinch 2012).

Norway and the United States have vastly disparate media and political systems, cultures, populations and conventions. More than 300 million individuals reside in the United States, a democracy marked by the diversity of its population as well as its geographical sprawl. In comparison, Norway, a nation of approximately 5 million people, is relatively homogenous and insular but provides a stronger social safety net and is more socially integrated. Beyond basic cultural and geographic differences, there are also clear political and media divergences between the two countries (Brüggemann et al. 2014; Aalberg \& Curran 2013).

The American media system is driven by “...market forces with minimal interference from the state..." and public media serve as small supplements to commercial outlets (Curran et al. 2009, 6). Historically, the primary sources of mass-mediated news and entertainment for Americans were local newspapers and broadcasters (Kaniss 1997). For many reasons, these media outlets offered a mix of local, national and international news produced by professional journalists who worked to inform (and attract) local audiences. Today, these traditional media organizations are struggling to hold an audience, numerous newspapers across the United States have closed, and many others are substantially diminished (McChesney \& Pickard 2011). Meanwhile, as the audiences for local (and network) television news decrease, corporate owners are reducing news staffs at stations across the country. 
The Norwegian media system is strongly shaped by state intervention in addition to free market forces. Media and communication services are conceptualized as public goods and the government provides strong support for public service broadcasting as well as subsidies for newspapers from disparate local communities and ideologies (Syvertsen et al. 2014). Though media choice proliferation gives public service broadcast outlets competition, the public options are still the most popular channels among Norwegians (Vaage 2013). While the number and reach of newspapers in the United States is declining, in Norway there are more local newspapers today than in 1995 and most of them offer online versions (Høst 2013). ${ }^{1}$

Cumulatively, the array of disparities between the United States and Norway provides an opportunity to see what effects the same macro change in their media environments - the expansion of media choice - yields in very different societies and media systems. Access to and use of the internet (one proxy for the expansion of choice) developed in a similar fashion from 1995-2012 in the two nations. ${ }^{2}$ Yet, despite access to similar media technologies, the opportunities for news exposure vary across the United States and Norway. As local news media contract in the United States, at least one measure indicates that they are expanding in Norway. Despite similar technology, the incentives for orienting towards local, national and international news also diverge in response to the political structure and climate in each nation.

\section{Media choice, news, and audience orientations}

Prior research suggests that media choice expansion precipitates a process of adaptation and integration among audience members (Becter \& Schoenbach 1989). To varying degrees, resources like time and money are scarce for individuals. Consequently, the advent of new communication options prompts behavioral changes as individuals seek to maximize gratification from their media use (Dimmick, Chen, \& Li 2004). For many people, the high choice environment presents an opportunity to avoid news entirely in favor of entertainment content (Aalberg, Blekesaune, \& Elvestad 2013; Prior 2007). The modern media environment does offer an abundance of entertainment choices - but it also provides access to many different sources and types of news. For some citizens, new media provide opportunities to create unique news diets that fulfil divergent information needs.

Digital media may be seen as substitutes in a smooth transition away from traditional news outlets (Trilling \& Schoenbach 2015), but there are some important caveats relating to news content in the modern media environment. First, following years of economic difficulty, the quantity and quality of local news produced by newspapers and local broadcasters is less robust today throughout the United States than it was before the rise of digital media - though, as noted above, this trend is not echoed in Norway (PEJ 2010). For international news, media organizations today can rely on the efforts of amateurs or non-media institutions to remotely cover global media events (at least superficially) which makes this content both cheaper and easier to produce (Hamilton 2010). Altogether, there are more news choices for the audience - American and Norwegian - but in some ways the environment may privilege national and international content at the expense of local content.

Evidence clearly shows that digital options are displacing the use of traditional media as sources of news (Gaskins \& Jerit 2012; Ha \& Fang 2012), but the leading news news 
websites are still national and owned by national and international media conglomerates. As the specific gratifications sought by individuals vary, so may their orientations toward local, national and international news. To strengthen proximate networks, one might seek local news content in order to be conversant about matters of community relevance (Merton 1949) or fulfil a desire for social integration, belonging and several other community-oriented needs (Costera Meijer 2010). Meanwhile, being worldly - or being seen as worldly - has advantages as well. In studies of influence (Merton 1949), people who are knowledgeable about world affairs are often identified as respected and persuasive - which may motivate some people to select international news. On the whole, choice expansion should increase the ability of audience members to successfully match a specific desire with specific content as they find their niche (Dimmick, Chen, \& Li 2004; Gaskins \& Jerit 2012).

\section{Hypotheses}

How, given the choice proliferation in the modern media landscape, have citizens' orientations towards local, national and international news changed? How consistent are these changes across national boundaries and media systems? With these questions in mind, and building upon the research introduced thus far, we posit several hypotheses to guide our analysis. First, following Prior (2007) and Blekesaune and colleagues (2012):

H1: Individuals in both the United States and Norway are more likely to be disconnected from news in 2012 than in 1995/1996.

Our second hypothesis stems from the notion that increased media choice allows individuals to easily tailor their media exposure. Given increased news media choice, we expect that audience members will choose to focus on issues that are specifically relevant to them instead of expressing their interest in news generally. Accordingly:

H2: Individuals in both the United States and Norway are less likely to be omnivorous in their orientation to news in 2012 than in 1995/1996.

Following this logic further, we might also expect individuals to be more specialized in their orientation towards news in 2012 than they were in 1995/96. Increased access to discrete sources of local, national and international news empowers individuals to select just the content they desire. Additionally, because of the shift in the relative accessibility and prominence of local, national, and international news, it may be that certain kinds of specialization are more likely today than in the past. For example, fewer people may be oriented towards just local news today while more people are oriented towards just national or international news. Such orientation patterns may further vary by nation considering, for example, the relative strength of local newspapers in Norway compared to the struggles of local news media in the United States. These complexities, as well as a scarcity of relevant prior evidence, limit our ability to hypothesize here. Instead, we offer a research question:

RQ1: How have patterns of news specialization by audience members in the United States and Norway changed between 1995/1996 and 2012? 
Finally, how might individual characteristics relate to changing patterns of news orientation? Recent research shows that younger individuals and women are less oriented to news than older people and men (Blekesaune, Elvestad, and Aalberg 2012; Wonneberger, Schoenbach, and Meurs 2013). In addition, women identify with their communities and prefer local news to international news - a divergence from the preferences of men (Morley 1992). There is also evidence that individuals with less education are more likely to orient to local matters rather than cosmopolitan affairs in the United States (Norris 2000) and Norway (Hagen 1994). Given these prior findings, we expect orientations towards news to vary between individuals according to their demographic characteristics - but because we are not certain that these variations will be consistent in the United States and Norway, we posit a second research question:

RQ2: How do gender, age and education relate to orientations towards local, national and international news in the United States and Norway?

\section{Data and method}

To compare patterns of news orientation in the United States and Norway, we use survey data collected by the Pew Research Center (U.S.) and TNS Gallup (Norway). These datasets include observations covering the same time period (1995/1996 to 2012) and they include similar variables that measure individuals' self-reported interest in (Norway) and attention to (U.S.) local, national and international news. Due to differences in question phrasing, these data are not directly comparable and we do not focus on comparing the proportion or number of news omnivores, disconnects and specialists across the two countries. Rather, we are primarily interested in the trends over time within the two countries - and the ways that these trends are similar (or dissimilar) in the two nations.

The Norwegian data are from the TNS Gallup, Forbruker \& Media undersøkelsen (The Consumer and Media Survey). This survey has been conducted annually since 1994. We use available data collected in 1995 and 2012. The sample was collected according to the following procedure: First, 30,000 persons were extracted from a representative sample of the Norwegian population, 15 years and above, for a telephone interview. At the end of each interview, the respondents were asked if they wanted to participate in a postal survey. In the second stage, approximately 20,000 people received a 98-page postal questionnaire that included questions about interest in news media. We use data from this postal survey in the analysis. The response rate for 1995 was not available, but the response rate reported for 2012 was 25 per cent. Unfortunately, TNS Gallup did not use the same questions in the period between 1995 and 2012. ${ }^{3}$ The U.S. data are drawn from random-digit dialing media consumption surveys conducted by the Pew Research Center's People and the Press project in 1996, 2004, and 2012. The response rate for the 1996 survey is not available; in 2004, it was 34 per cent and it dropped to less than 10 per cent in 2012. Despite this downward trend, Pew employs several tactics to ensure that each survey includes a representative sample of American adults.

\section{Dependent variables}

The typology of different orientations towards local, national and international news that we employ for our dependent variables is presented in Table 1. 
Table 1. Types of news orientation

\begin{tabular}{|l|l|}
\hline Omnivores & Strong orientation towards news on all levels \\
\hline Disconnected & Weak orientation towards news on all levels \\
\hline Locals/Local Specialists & $\begin{array}{l}\text { Stronger orientation towards local news than national } \\
\text { or international news }\end{array}$ \\
\hline National Specialists & $\begin{array}{l}\text { Stronger orientation towards national news than local } \\
\text { or international news }\end{array}$ \\
\hline $\begin{array}{l}\text { Cosmopolitans/International } \\
\text { Specialists }\end{array}$ & $\begin{array}{l}\text { Stronger orientation towards international news than } \\
\text { national or local news }\end{array}$ \\
\hline $\begin{array}{l}\text { Local-Nationals } \\
\text { Local-Internationals } \\
\text { National-Internationals }\end{array}$ & $\begin{array}{l}\text { Strong orientation to two of the three types of news } \\
\text { (as named) }\end{array}$ \\
\hline
\end{tabular}

The dependent variables are constructed by sorting respondents into categories of news orientations based on the specific news content (local, national, or international) that they report either being interested in (Norway) or following (U.S.). To quantify news orientation in the Norwegian sample, we use three questions that probe local, ${ }^{4}$ national, and international ${ }^{5}$ news interest separately with this format:

How interested are you in XXXX news?" (very interested, somewhat interested, somewhat uninterested, uninterested)

The frequencies of these variables (Table 2) show that respondents in the Norwegian sample have great interest in the news. To be considered as orienting towards any of the three levels, the respondents have to answer "very interested." For instance, an individual who indicates that she is "very interested" in local news and less interested in the other news types is classified as possessing an orientation towards local news. Similarly, a respondent who reports being "very interested" in local and national news (but not international news) is classified as a local-national. Finally, a respondent who is "very interested" in local, national and international news is classified as an omnivore.

To determine orientation towards news in the U.S. sample, we use four measures drawn from a battery of items that probed respondents' attention to news about political figures and events in Washington, international affairs, people and events in your own community or local government in the following format:

Please tell me how closely you follow XXXX either in the newspaper, on television, radio or the internet...? (very closely, somewhat closely, not very closely, not at all closely)

These specific questions were asked of all respondents in 1996 and 2004. In 2012, a splitballot design alternated between asking respondents about local government or people and events in your own community. Respondents in the United States were defined as orientating towards specific news content if they indicated that they followed it either "very closely" or "somewhat closely." In order to avoid losing 50 per cent of U.S., we pooled the respondents' attention to local government and people and events in your own community to create a generalized local news variable. ${ }^{7}$ 
Table 2. Basic descriptives (weighted)

\begin{tabular}{|c|c|c|c|c|c|c|}
\hline & \multicolumn{3}{|c|}{ Norway } & \multicolumn{3}{|c|}{ United States } \\
\hline & 1995 & 2005 & 2012 & 1996 & 2004 & 2012 \\
\hline \multicolumn{7}{|l|}{ Education: } \\
\hline Less Than HS & $19.4 \%$ & $12.4 \%$ & $9.1 \%$ & $22.7 \%$ & $20.2 \%$ & $17.4 \%$ \\
\hline HS \& Some College & $50.9 \%$ & $42.6 \%$ & $42.2 \%$ & $58.1 \%$ & $55.9 \%$ & $55.1 \%$ \\
\hline College \& Post-Grad & $29.6 \%$ & $44.8 \%$ & $48.2 \%$ & $19.2 \%$ & $23.9 \%$ & $27.4 \%$ \\
\hline \multicolumn{7}{|l|}{ Gender: } \\
\hline Female & $51.3 \%$ & $50.9 \%$ & $50.1 \%$ & $51.8 \%$ & $52.9 \%$ & $50.6 \%$ \\
\hline Age (years) & 44.9 & 46,86 & 47.4 & 42.2 & 45.6 & 49.0 \\
\hline \multicolumn{7}{|c|}{ Orientation towards news: } \\
\hline \multicolumn{7}{|l|}{ News Interest (1-4) } \\
\hline Local* $^{*}$ & $\begin{array}{l}3.66 \\
(.52)\end{array}$ & - & $\begin{array}{l}3.51 \\
(.67)\end{array}$ & & & \\
\hline National & $\begin{array}{l}3.59 \\
(.55)\end{array}$ & - & $\begin{array}{l}3.59 \\
(.58)\end{array}$ & & & \\
\hline International & $\begin{array}{l}3.39 \\
(.67)\end{array}$ & - & $\begin{array}{l}3.33 \\
(.70)\end{array}$ & & & \\
\hline \multicolumn{7}{|l|}{ News Attention (1-4) } \\
\hline Local & & & & $\begin{array}{l}2.90 \\
(.78)\end{array}$ & $\begin{array}{l}2.78 \\
(.84)\end{array}$ & $\begin{array}{c}2.76 \\
(1.00)\end{array}$ \\
\hline National & & & & $\begin{array}{l}2.59 \\
(.90)\end{array}$ & $\begin{array}{l}2.78 \\
(.98)\end{array}$ & $\begin{array}{l}2.57 \\
(.99)\end{array}$ \\
\hline International & & & & $\begin{array}{l}2.60 \\
(.90)\end{array}$ & $\begin{array}{l}2.74 \\
(.99) \\
\end{array}$ & $\begin{array}{l}2.48 \\
(.98)\end{array}$ \\
\hline $\mathrm{N}$ & 12978 & 9296 & 11012 & 1729 & 2932 & 1455 \\
\hline
\end{tabular}

The numbers are mean values and standard deviations are shown in parentheses.

*In 1995, local news is a combination of interest in news about county and news about municipality. Respondents get the highest value from these variables on the new local variable.

Table 2 contains an overview of the weighted survey samples, parsed by nation and year. The Norwegian sample is weighted according to gender, age and place of living by TNS Gallup. To analyze the Pew/U.S. data, we created weights to match the proportional age, gender, and education of the survey samples with average population parameters drawn from the April, 1996 and May, 2012 U.S. Current Population Survey (CPS). In our regression models, we also include three demographic variables: age, education, and gender. ${ }^{8}$

\section{Results}

Figure 1 illustrates how orientations towards news have changed from 1995/96 to 2012 in Norway and the United States. There is a significant decrease in the number of omnivores in Norway $(\mathrm{MD}=11.0 \%, \mathrm{p}<.001)$. In the United States, there are significantly more disconnected people in 2012 than in 1996/2004 but this is not the case in Norway. The patterns of specialization appear to change in both nations as well. Between 1995/96 and 2012, the number of local specialists significantly decreases in Norway and the United States. In Norway, there are also significantly more national and international 

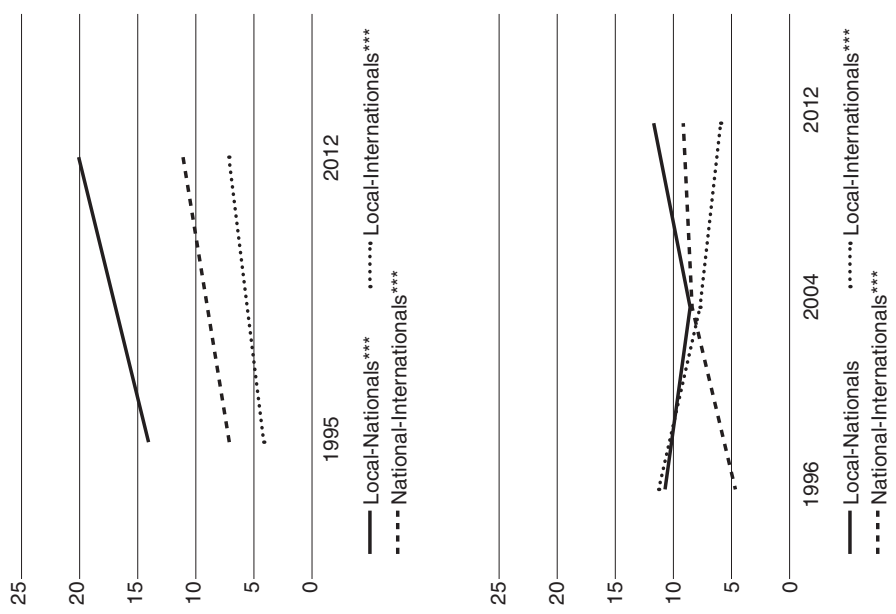

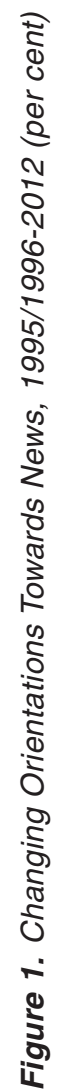
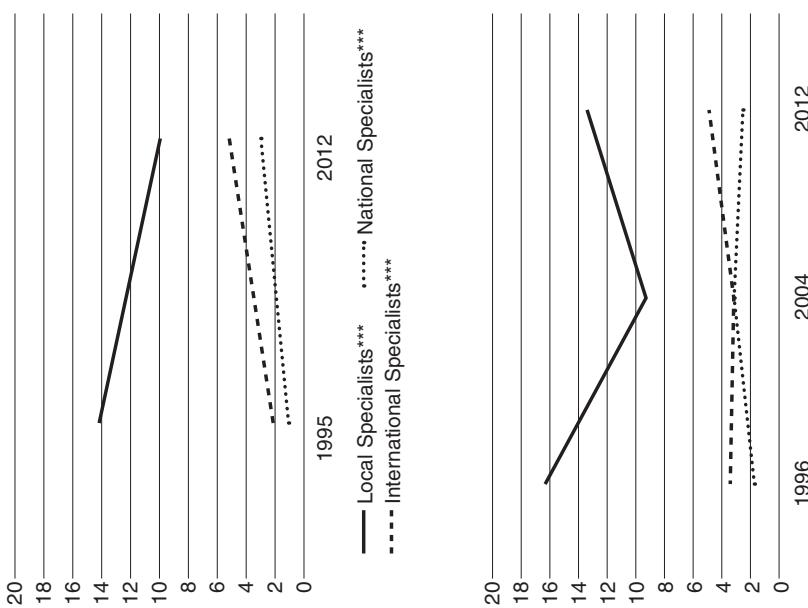

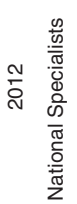

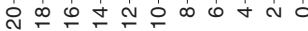

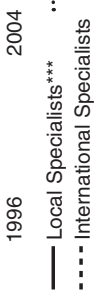

栾
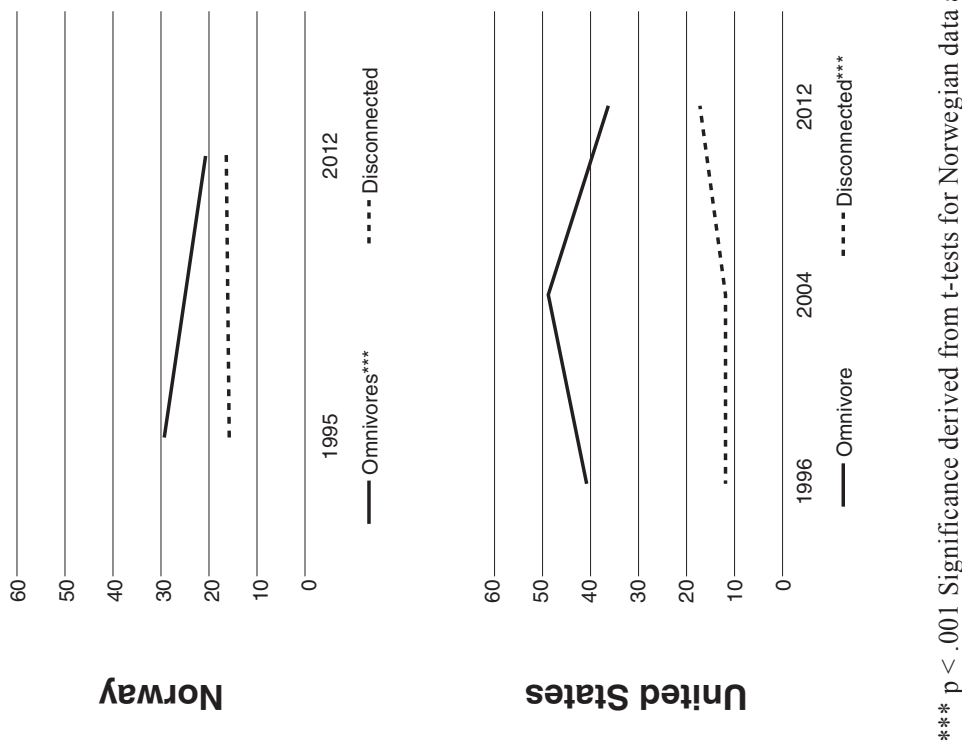
specialists in 2012 than there were in 1995. The patterns between the two nations further diverge when two news types are considered. In Norway, there are significant increases in the number of local-nationals and national-internationals. And, on the whole, there are substantially more respondents who orient to two news types in 2012 (31.7 per cent) versus 1995 (21.8 per cent). In the United States, the overall tally of people oriented towards two news types is flat over time - but there are more national-internationals and fewer local-internationals.

Further analysis is required to verify the trends depicted in Figure 1. Tables 3A and 3B contain the results of eight separate logistic regressions, for each country, designed to depict how news orientations changed from 1995/6 to 2012 (see Appendix Table A for supplemental analysis of similar Norwegian data from 2000-2010).

\section{Norway}

Analyses controlling for age, gender, and level of education provide additional support for $\mathrm{H} 1$ and suggest that a number of Norwegians disconnected from news between 1995 and $2012\left(\chi^{2}=1364, \mathrm{R}^{2}=.09\right)$. Respondents were about 13 per cent more likely not to report being "very interested" in local, national, and international news simultaneously in 2012 than they were in 1995. Men were more likely to be disconnected and older respondents were less likely to be disconnected. There were no significant differences across levels of education for the disconnected dependent variable.

At the same time, fewer Norwegians reported omnivorous interest in the news in 2012 than in 1995. The results of this model support H2 and are the strongest of our regressions $\left(\chi^{2}=1708, \mathrm{R}^{2}=.10\right)$. This model also shows that education is positively correlated with an omnivorous news orientation. In addition, age positively predicts having omnivorous news interest: respondents are about 3 per cent more likely to be omnivorous for each additional year of age. In this model, there are no significant gender differences.

As Norwegians shift away from omnivorous news orientation, they are becoming more likely to focus on two news types. The number of local-nationals, local-internationals and national-internationals all increased significantly from 1995-2012. The number of local-internationals is small and does not change much, but like the local-nationals and national-internationals the group did expand. Notably, men are less likely to be local-nationals than women - but more likely to be national-internationals. Education is negatively associated with being a local-national but positively associated with being a national-international.

Finally, there is mixed evidence in the change in orientation towards one type of news. In the 1995 and 2012 comparison, Norwegians are less likely to be local news specialists but more likely to be national or international specialists. As above, this pattern also correlates with educational attainment - which is higher for respondents in the 2012 sample (Table 2). Respondents who have less education are more likely to be local news specialists than the most educated respondents. At the same time, respondents who have less education are less likely to be oriented specifically towards national or international news. Meanwhile, men are less likely than women to be interested solely in local news but more likely than women to be interested solely in international news. There is no gender difference in national news interest. Age is negatively associated with all forms of news interest specialization among the Norwegian respondents. This 


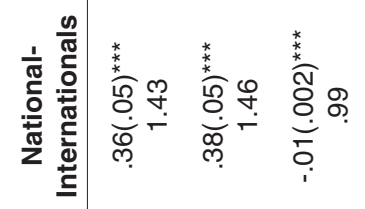

产

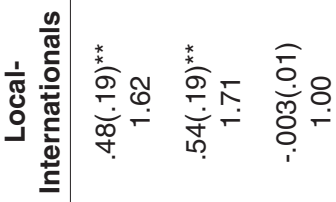

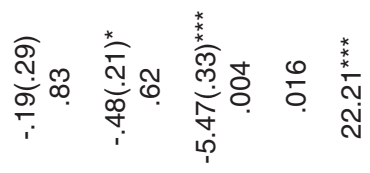

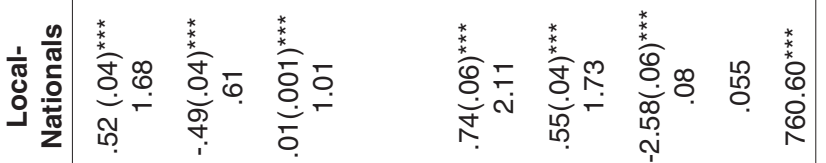

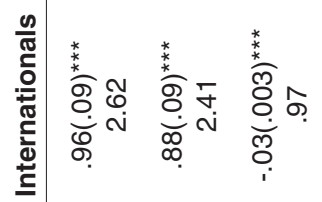

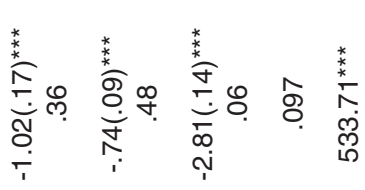

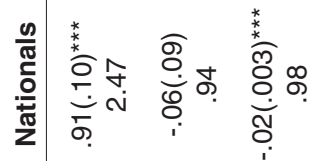

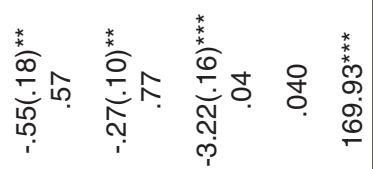

शे

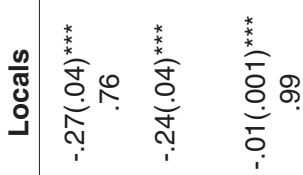

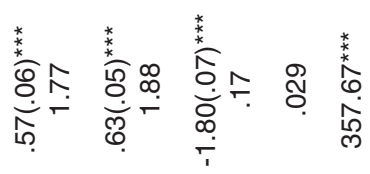

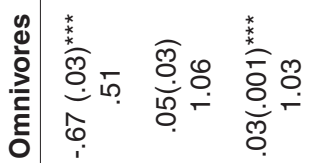

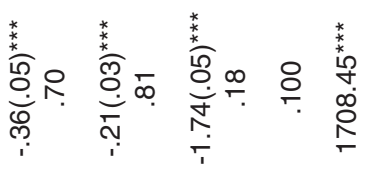

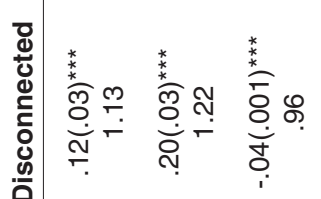

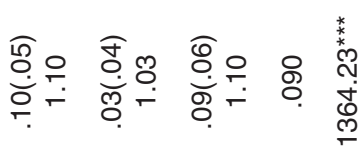

s)

(2)

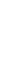<smiles>C1=C[Al]CC1</smiles>

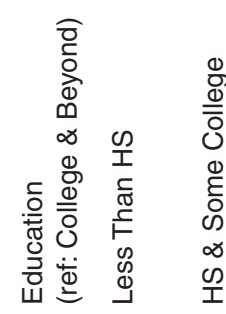
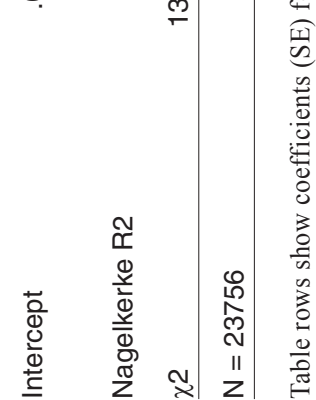


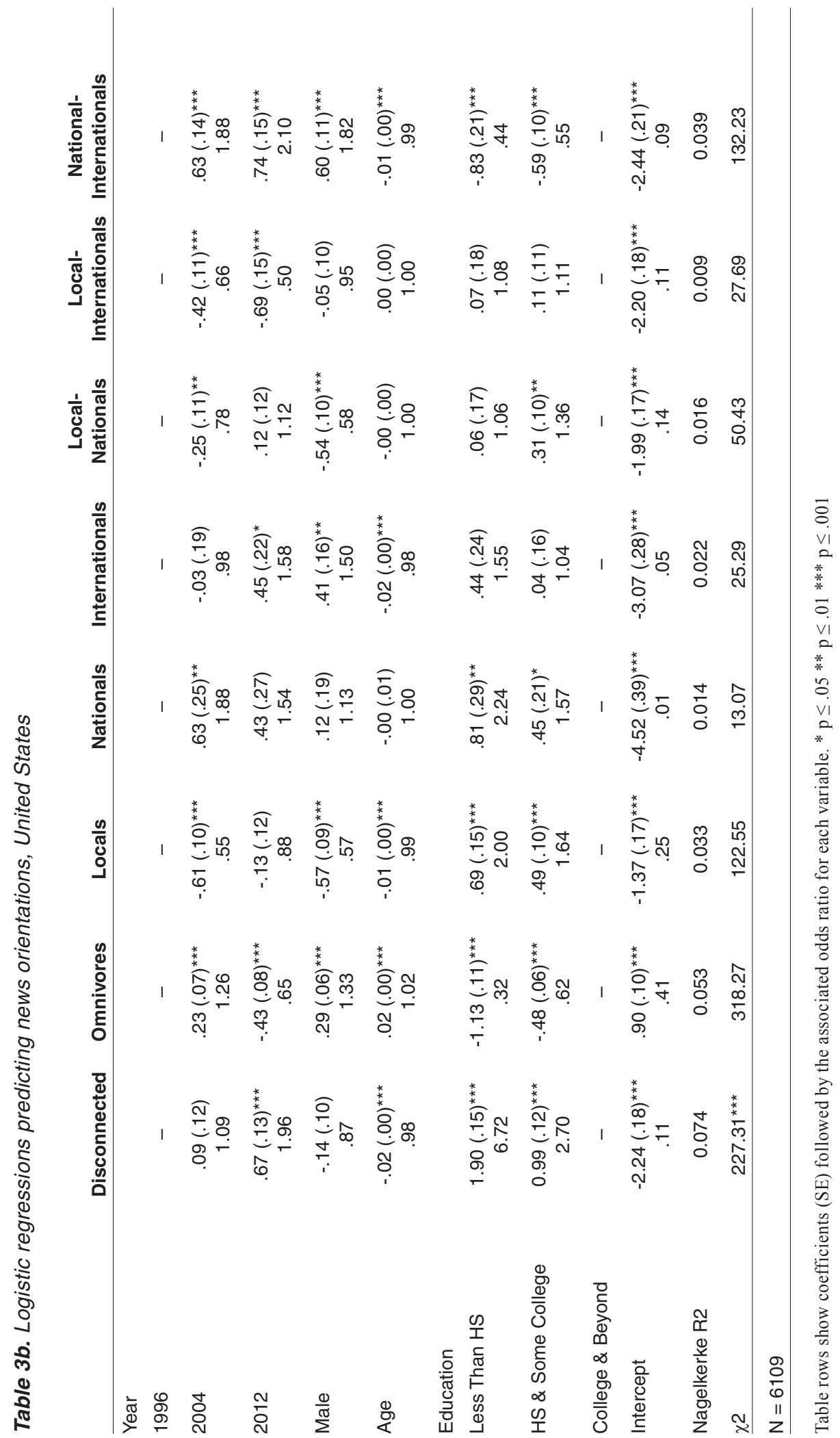


implies that younger people are more likely to be either disconnected or specialized in their news orientation than their older counterparts.

\section{United States}

In the United States, the regressions support $\mathrm{H} 1$ and show that people are significantly more likely to be simultaneously disconnected from local, national, and international news in 2012 than they were in 1996. This model also shows that education is a significant predictor of being disconnected: compared to respondents with a college or graduate degree, those with less than a high school education and those with a high school (and perhaps some college) education are substantially more likely to be disconnected. Gender differences are not significant in this model, but age is a significant, negative predictor of being disconnected.

Meanwhile, as predicted in $\mathrm{H} 2$, American respondents were significantly less likely to be omnivorous news consumers in 2012 than in 1996 - but were significantly more likely to be omnivorous in 2004. In this model, there is a gender difference: men are significantly more likely to be omnivorous than women. Education is strongly associated with being an omnivore: less educated respondents are less likely to be omnivorous news consumers. Finally, age is a significant, positive predictor of being a news omnivore.

The specialization and two-news type regressions produce mixed results that do not clearly replicate the Norwegian analyses. Americans were significantly less likely to be local-nationals in 2004 compared to 1996 - but there is no significant difference between 1996 and 2012. In the U.S., respondents were significantly less likely to be a local-internationals in both 2004 and 2012 but significantly more likely to be nationalinternationals in both years (compared to 1996). Meanwhile, as in Norway, the number of national-internationals increased substantially over time. The gender patterns observed in the two-news type models echo the Norwegian relationships: men are less likely to be local-nationals but more likely to be national-internationals. Additionally, respondents with lower levels of education are less likely to be national-internationals than those with at least a college degree.

In the specialist models, change over time is inconsistent. Americans were significantly less likely to be local specialists in 2004 than in 1996 - but there is no difference between 1996/2012. Meanwhile, they were significantly more likely to be national specialists in just 2004 and international specialists in just 2012. Men are significantly less likely to orient singularly towards local news than women and respondents who are either younger or have less formal education are more likely to focus exclusively on local news. People who are less educated are more likely to be national specialists; men are more likely to be international specialists and age is negatively associated with focusing solely on international news.

\section{Discussion}

Previous research in the United States (Prior 2007) and Europe (Aalberg, Blekesaune, and Elvestad 2013) indicates that media choice expansion allows people to tailor their media diets - often in order to avoid news in favor of entertainment. In this study, we add detail to this body of work by illustrating how choice relates to individuals' ori- 
entations toward local, national and international news with a unique cross-national, over-time design. Taking a broad view, we find that the data from the United States and Norway tell a similar story of change in citizens' orientations towards local, national and international news from 1995/96 to 2012 - but there are interesting differences as well.

Our data indicate that fewer respondents in both nations were omnivorous in their news orientation in 2012 than in 1995/6. But more people were omnivorous in the United States in 2004 than at either other time point - perhaps as a result of pressing current events. Meanwhile, evidence shows that more respondents disconnected from all news in both nations over time. This change is much more pronounced in the United States; in Norway, there are only a few more disconnected individuals today, but there are many more individuals who are oriented towards two types of news. Norwegians, who are traditionally avid news users, may be earlier in the transition towards news avoidance that Prior (2007) depicts in the United States. Alternately, the political and media contexts in Europe, and the Nordic countries in particular, could lead more Norwegians to stay in a "specialization phase" without abandoning news. Time will reveal which of these hypotheses is more accurate, but for now, data suggests that Norwegians are growing more particular in their news orientation. In the United States, respondents are more likely to have disconnected from news in the past 16 years than they are to have specialized. Data from the General Social Survey over this period consistently show that very few Americans have confidence in news media or the government. Empowered by the expansion of media choice, they can now more easily avoid news about matters (like government) that they feel alienated from. Therefore, superficially, the shifts towards specialization in Norway and the United States appear similar - but the nuances and explanations of these patterns diverge.

As part of this shift towards selectivity by Norwegian and American audiences, there are news-type winners and losers. Local news, long of primary interest to audiences in both countries, is still important to many audience members. But, orientation towards local news seems to be dwindling - particularly in the United States. As people have access to more choice and grow more selective, if they orient to news at all, they are shifting towards national and international news. Though subsidies can prop up local newspapers (and their websites) in Norway, declining audience interest may eventually lead to a local journalism crisis familiar to observers in other nations (Nielsen 2015).

Turning to demographic characteristics, the clearest gender difference in both countries is evidence that women are more likely to be local specialists while men are more likely to be international specialists. This trend persists over time, is echoed in the twonews type models and generally conforms to the findings of previous research about gender and political knowledge/behavior (Verba, Burns, and Schlozman 1997). Put simply, men and women have different interests that relate to well-established gender roles and are reflected in their news orientations. Age also predicts different news orientations in our data. Younger people are more often disconnected, less likely to be omnivores and more likely to be specialists than older people in both the United States and Norway. If young people follow any news, they are more likely to focus their attention on one type of news. News orientation develops over the lifespan and, for young people today, the gamut of news may eventually be of greater interest at later developmental stages. But, today's young people are coming of age in an era of media customization and abundance. Personalized choice - via recommendations or algorithms from Netflix, Facebook, and 
a host of other media purveyors - is the norm. Instead of aging into generalists, it is possible that today's young people are habituated to narrowly targeted content and will remain news specialists going forward.

\section{Conclusion}

The incentives for orienting towards news - in general and of different levels - vary substantially depending on social and political context. Norwegians live in a small, more tightly knit society and have closer ties to their local communities and the national government. Many Americans live in large, sprawling metropolitan areas and are disconnected from each other as well as from politics. In these disparate settings, the perceived value of news differs. Placed within national context, differences in individuals' responses to increased media choice make sense.

Regardless of the continuing technological transition, local, national and international news are important forces of integration in societies that support democratic processes in many different (and discrete) ways. To examine the contributions of news to society, it is not enough to study users and non-users of news. Rather, it is necessary to parse news orientations - and changes in these orientations - more granularly. As media choice increases, it is vital to better understand who selects which news content for what reasons under which circumstances. Societies that expect broad, informed citizen participation in democratic processes on different levels cannot afford to take local, national or international news use for granted. Individual and contextual differences produce nuanced audience behaviors that we should strive to comprehend more completely.

\section{Notes}

1. In 1995, there were 168 communities in Norway with at least one paid for newspaper, and 218 newspapers published. In 2012 there were 227 paid-for newspapers published in 185 locales (Høst 2013). The increase in numbers of local newspapers is caused by an increase in non-daily local newspapers.

2. In 1995, only 5per cent of Norwegians used the internet weekly (Vaage 1997). By 2012, 91 per cent of Norwegians reported weekly internet use and 95 per cent of Norwegians had internet access at home (Vaage, 2013). In the United States, internet use increased from 23 per cent of adults in 1996 to more than 80 per cent by 2012 (Pew 2014).

3. To provide additional context for our Norwegian findings, we include analyses of data of somewhat comparable questions from 2000, 2005 and 2010 in an appendix.

4. In 1995, respondents were asked two questions about local news. In the first question, they were asked about their interest in what is happening in their county. In the second question, they were asked about their interest in what is happening in their municipality. For our analysis, those who are very interested in either one of these kinds of news or both will be coded as locals.

5. In 1995, the question was formulated as, "How interested are you in news about the world?"

6. Self-reports of news interest and news attention are, clearly, different - yet both are indicative of respondents' news orientations. Setting aside the issue of self-reporting (Prior 2009), to espouse interest in a topic requires less of respondents than actual consumption and, in recognition of this, our dependent variables are constructed differently for interest (Norway) and attention (United States). In our formulation, reported interest must be higher than reported attention to indicate orientation. Still, this obvious difference in our data across contexts is another reason that we do not directly compare the effect sizes that we observe in the two nations.

7. All respondents answered both questions in 1996 and 2004, so our local variable is an average of the two responses. In 2012, the variable is set equal to whichever item out of the pair that respondents answered.

8. The Pew surveys include race and income as well, but the Norwegian dataset do not. For comparative purposes, we therefore do not include these variables in our models. 


\section{References}

Aalberg, Toril; Blekesaune, Arild, \& Elvestad, Eiri (2013). Media Choice and Informed Democracy: Toward Increasing News Consumption Gaps in Europe? The International Journal of Press/Politics, May, 1940161213485990. doi:10.1177/1940161213485990.

Aalberg, Toril, \& Curran, James (eds) (2013). How Media Inform Democracy: A Comparative Approach. Reprint edition. Routledge.

Becker, Lee B., \& Schoenbach, Klaus (1989). When Media Content Diversifies: Anticipating Audience Behaviors. In Audience Responses To Media Diversification: Coping With Plenty, edited by Lee B. Becker \& Klaus Schoenbach, 1-28. Hillsdale, N.J: Routledge.

Bijker, Wiebe E., Hughes, Thomas P., \& Pinch, Trevor (eds) (2012). The Social Construction of Technological Systems: New Directions in the Sociology and History of Technology. Anniversary edition edition. Cambridge, Mass: The MIT Press.

Blekesaune, Arild; Elvestad, Eiri \& Aalberg, Toril (2012). Tuning out the World of News and Current Affairs - An Empirical Study of Europe's Disconnected Citizens. European Sociological Review 28(1): 110-126. doi:10.1093/esr/jeq051.

Brüggemann, Michael, Sven Engesser, Florin Büchel, Edda Humprecht, \& Laia Castro (2014). Hallin \& Mancini Revisited: Four Empirical Types of Western Media Systems. Journal of Communication 64(6): 1037-1065. doi:10.1111/jcom.12127.

Costera Meijer, Irene (2010). Democratizing Journalism? Journalism Studies 11(3): 327-142. doi:10.1080/14616700903500256.

Curran, James; Iyengar, Shanto; Lund, Anker Brink, \& Salovaara-Moring, Inka (2009). Media System, Public Knowledge and Democracy A Comparative Study. European Journal of Communication 24(1): 5-26. doi:10.1177/0267323108098943.

Delli Carpini, Michael X., \& Keeter, Scott (1997). What Americans Know about Politics and Why It Matters. Yale University Press.

Dimmick, John; Chen, Yan, \& Li, Zhan (2004). Competition Between the Internet and Traditional News Media: The Gratification-Opportunities Niche Dimension. Journal of Media Economics 17(1): 19-33. doi:10.1207/s15327736me1701_2.

Elvestad, Eiri (2009). Introverted Locals or World Citizens? A Quantitative Study of Interest in Local and Foreign News in Traditional Media and on the Internet. Nordicom Review: Nordic Research on Media \& Communication 30(2): 105-124.

Gaskins, Benjamin, \& Jennifer Jerit (2012). Internet News Is It a Replacement for Traditional Media Outlets? The International Journal of Press/Politics 17(2): 190-213. doi:10.1177/1940161211434640.

Hagen, Ingunn (1994). Expectations and Consumption Patterns in TV News Viewing. Media, Culture \& Society 16(3): 415-428. doi:10.1177/016344379401600304.

Ha, Louisa, \& Ling Fang (2012). Internet Experience and Time Displacement of Traditional News Media Use: An Application of the Theory of the Niche. Telematics \& Informatics 29(2): 177-186. doi:10.1016/j. tele.2011.06.001.

Hamilton, James T. (2010). The (many) Markets for International News. Journalism Studies 11(5): 650-666. doi:10.1080/1461670X.2010.502789.

Høst, Sigurd (2013). Avisåret 2013 (The Year of Newspapers 2013). Rapport:Høgskolen I Volda. http://www. hivolda.no/rapport.

Kaniss, Phyllis (1997). Making Local News. University Of Chicago Press.

McChesney, Robert W., \& Pickard, Victor (2011). Will the Last Reporter Please Turn out the Lights: The Collapse of Journalism and What Can Be Done To Fix It. New Press, The.

Merritt, Davis, \& Rosen, Jay (1995). Imagining Public Journalism: An Editor and Scholar Reflect on the Birth of an Idea. Roy W. Howard Project, School of Journalism, Indiana University.

Merton, Robert K. (1949). Patterns of Influence: A Study of Interpersonal Influence and of Communications Behavior in a Local Community. In Communication Research 1948-1949, edited by Lazarsfeld, Paul F., \& Stanton, Frank N. New York: Harper \& Brothers.

Merton, Robert K. (1968). Social Theory and Social Structure. Simon and Schuster.

Morley, David (1992). Television, Audiences and Cultural Studies. 1 edition. London; New York: Routledge.

Nielsen, Rasmus Kleis (2015). Local Journalism: The Decline of Newspapers and the Rise of Digital Media. I. B. Tauris.

Norris, Pippa (2000). A Virtuous Circle: Political Communications in Postindustrial Societies. Cambridge University Press.

PEJ (2010). How News Happens: A Study of the News Ecosystem of One American City. Project for Excellence in Journalism. http://www.journalism.org/analysis_report/how_news_happens.

Pew (2014). Internet Use Over Time. Pew Research Center: Internet, Science \& Tech. January 2. http://www. pewinternet.org/data-trend/internet-use/internet-use-over-time/. 
Prior, Markus (2007). Post-Broadcast Democracy: How Media Choice Increases Political Inequality and Polarizes Elections. New York: Cambridge University Press.

Prior, Markus (2009). The Immensely Inflated News Audience: Assessing Bias in Self-Reported News Exposure. Public Opinion Quarterly 73(1): 130-143. doi:10.1093/poq/nfp002.

Rainie, Lee, \& Wellman, Barry (2012). Networked: The New Social Operating System. The MIT Press.

Shaker, Lee (2012). Local Political Knowledge and Assessments of Citizen Competence. Public Opinion Quarterly 76(3): 525-537. doi:10.1093/poq/nfs018.

Stamm, Keith R. (1985). Newspaper Use and Community Ties : Toward a Dynamic Theory. Norwood, N.J.: Ablex Pub. Corp.

Syvertsen, Trine; Mjøs, Ole J.; Moe, Hallvard, \& Enli, Gunn Sara (2014). The Media Welfare State: Nordic Media in the Digital Era. Ann Arbor: University of Michigan Press.

Trilling, Damian, \& Schoenbach, Klaus (2015). Investigating People's News Diets: How Online Users Use Offline News. Communications-European Journal of Communication Research 40(1): 67-91. doi:10.1515/ commun-2014-0028.

Vaage, Odd Frank (1997). Norsk Mediebarometer 1997. Oslo: Statistisk Sentralbyrå.

Vaage, Odd Frank (2013). Norsk Mediebarometer 2013. Oslo: Statistisk Sentralbyrå.

Verba, Sidney; Burns, Nancy \& Schlozman, Kay Lehman (1997). Knowing and Caring about Politics: Gender and Political Engagement. The Journal of Politics 59(4): 1051-1072. doi:10.2307/2998592.

Wonneberger, Anke; Schoenbach, Klaus \& Meurs, Lex van (2013). How Keeping up Diversifies. European Journal of Communication 28(6): 646-662. doi:10.1177/0267323113501150.

EIRI ELVESTAD, Ph.D., Associate Professor, Department of Business, History and Social Sciences, University College of Southeast Norway, eiri.elvestad@usn.no LEE SHAKER, Ph.D. Assistant Professor, Department of Communication, Portland State University, USA, lshaker@pdx.edu 


\section{Appendix}

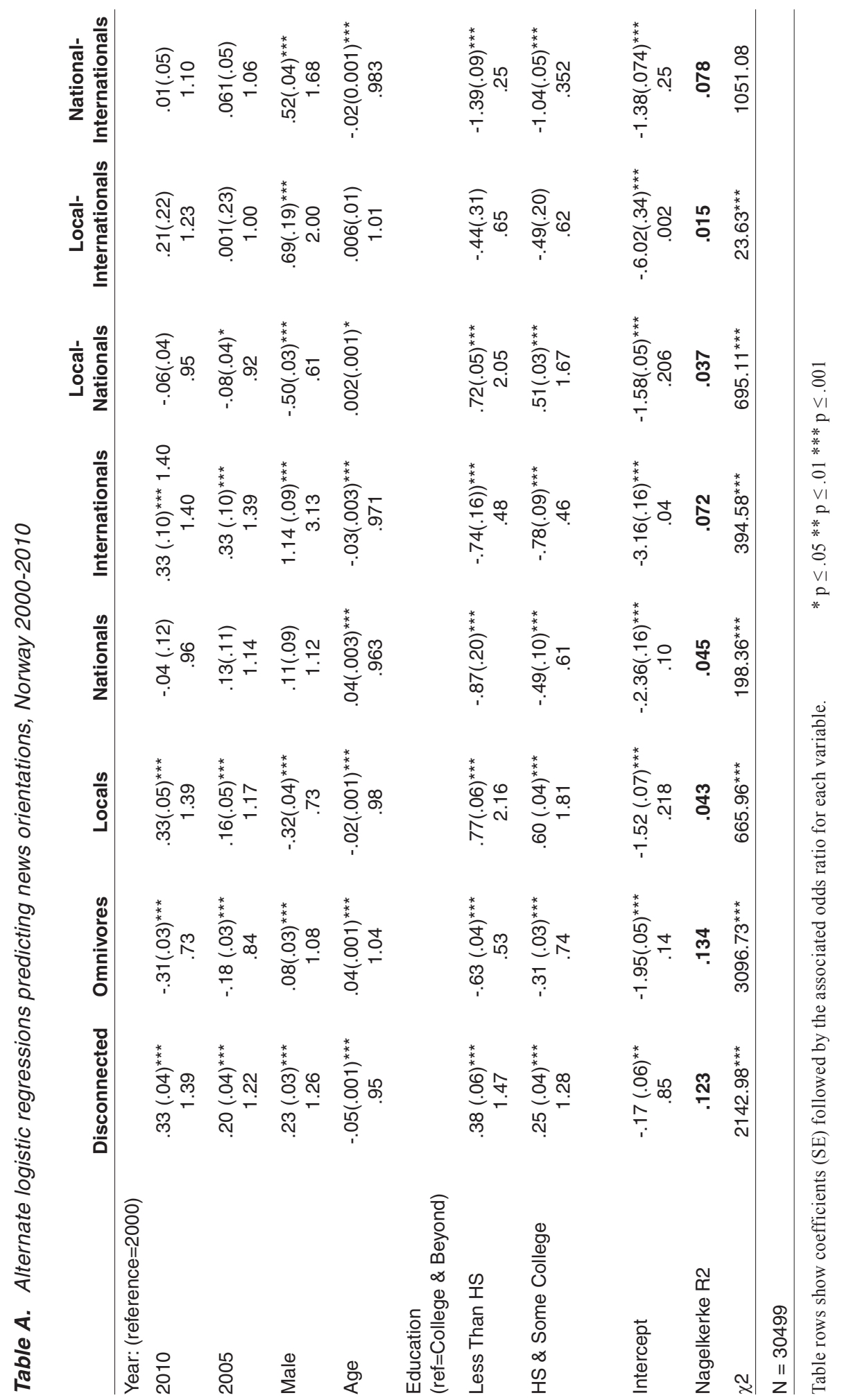

